\title{
The Effect of Architecture of Arts Education Tourism Towards Interest in Learning Arts for High School Students
}

\author{
Agus Budiman $\bowtie$, Trianti Nugraheni, Purnomo Purnomo \\ Universitas Pendidikan Indonesia, Indonesia
}

Submitted: June 8, 2020. Revised: October 19, 2020. Accepted: November 24, 2020

\begin{abstract}
The implementation of tourism activities not only has a purpose for traveling or entertainment. In education, tourism can have a function as a learning activity carried out by someone in their visit to a tourist attraction location. This study aims to determine the effect of organizing an art education tour on the interest in learning art for high school students. This study uses a quantitative research approach with a sample of 84 students who took part in an art education tourism program held at UPI (Indonesian University of Education). This study took a sample using total sampling techniques in which all respondents were taken into consideration the analysis of research data. Data collection used in this study is to use a closed questionnaire in the form of a scale. Research data analysis uses simple regression test data analysis techniques to find out whether there is an influence of art education tourism activities on high school students' interest in learning art at school. The results of the study can be concluded that educational tours have an influence on high school students' interest in learning art; this is indicated from the results of the coefficient of determination (R Square) of 0.479 , which implies that the influence of educational programs on the dependent variable (interest in learning art) is $47.9 \%$. The results of the analysis show how much the independent variable $(\mathrm{X})$ can affect the dependent variable $(\mathrm{Y})$.
\end{abstract}

Keywords: educational tours; art education tourism; art learning interest

How to Cite: Budiman, A., Nugraheni, T., \& Purnomo. (2020). The Effect of Architecture of Arts Education Tourism Towards Interest in Learning Arts for High School Students. Harmonia: Journal of Arts Research And Education, 20(2), 117125

\section{INTRODUCTION}

Rencana Kerja Pemerintah (RKP) or the Government Plan year 2018, encourages development with a focus on three priority sectors whose roles will be enhanced for growth and job creation, namely the processing industry, agriculture, and tourism. As one of the priorities, the tourism sector needs to be seriously developed so that it can have a significant impact on the economy for the actors in it. Several types of work fields in the tourism sector include nature tourism, cultural tourism, historical tourism, educational tourism, agricultural tourism, religious tourism, marine tourism, and culinary tourism.

Edu-Tourism or educational tourism is intended as a program where participants in tourism activities take a tour of a certain place in a group to gain learning experiences directly related to the location visited. The definition of educational tourism is a program that combines elements of tourism activities with educational content in it. The concept of educational

\footnotetext{
Corresponding author:

E-mail: agusbudiman@upi.edu
} 
tourism is more about combining the concept of study tour visits on an object that is intended (Suprihanto et al., 2020). This program can be packaged in such a way as to make annual tourism activities or extracurricular activities become more quality.

Educational tourism is a tour that has added educational value, not just traveling but also aims to add educational values for tourists (Hasanah, 2018). Usually, educational tourism destinations are places that have added value as a tourist area, such as plantation areas, zoos, breeding places for rare animals, research centers, museums, etc. The tourism material adjusted to the interest of the object and the field of science to be studied. Educational tours aim to increase the intelligence and creativity of tourism activity participants.

Universitas Pendidikan Indonesia (UPI) is one of the campuses with the label education. Along with the change in the status of UPI from PT BHMN to PTN$\mathrm{BH}$ based on the provisions of the Higher Education Law Number 12 of 2012, in general, this university shows a change in the higher education management system, namely UPI has the authority and independence in managing its campus, both in the field academic and non-academic services.

The change in the status of UPI from PT BHMN to PTN-BH must be balanced wisely by the entire university community, which is marked by a change in the paradigm of thinking to manage university autonomy well.

All forms of campus potential, both the physical potential of facilities (facilities and infrastructure) and campus human resources, need to be properly optimized to be managed based on the management mechanism to support the achievement of the university's vision and mission. It is aspired to in various policy programs written in the university's strategic plan year 2016-2020. From some of the university's authority and independence related to UPI's status as PTN-BH, it is interesting and challenging to think that the university in its management is the autonomy of managing various assets and facilities that can be developed as a potential strategy. It is for developing and seeking university funding sources from various educational service products and partnership services with various agencies to provide the university's financial income.

One of the strategic potentials that the university can develop is to develop the concept of campus-based educational tourism by empowering all the potential that the University has, both the potential for human resources and the facilities and infrastructure owned by UPI. Every week, the University of Education facilitates high school students for study tours and comparative study to the UPI campus. This comparative study aims to promote UPI to high school students, especially those who wish to continue to higher education. Besides, high school students are given cultural arts or performances to welcome newcomers or guests to the UPI campus.

At this moment, of course, it becomes an opportunity for the Faculty of Art and Design (FPSD) to attract students' interest in cultural arts and even eventually, they love cultural arts and want to study it. It is hoped that educational tourism can increase students' interest in learning about art. According to (Andriana, 2017), Brougère (2013), (Morellato, 2014), students' interest in learning is still lacking. They attend school but only for obligation, especially art courses with only a few hours. Various studies show that educational tourism makes a positive contribution to students (Arici et al., 2014).

The purpose of art education is not merely to make a student become an artist, but to make the student experience creating art to have a love and sense of belonging to art, as described in (Sunaryo et al., 2020). This condition explains that the role of art education in schools must develop the students' potential (Sabri et al., 2019); (Lisetskaya et al., 2019). These learning conditions will make students more likely to develop their respective potentials. Art education is an alternative in introducing art that is rooted in the nation's culture, as well as a filter for the entry of foreign cul- 
tures that are aggressively hitting our culture. Besides, it is also an effort to balance the increasing priority of education on the intellectual side. Art has benefits for the intelligence of the students' souls who can refine and deepen the soul's movements so that it is expected to improve the students' character.

Art education in schools is practically interpreted as an effort to shape students' skills to have skills in the arts they are studying. However, learning time is limited, so educational tourism is an additional alternative to obtain art and cultural material from other sources outside of school. So, related to this, the researchers try to find the influence of the implementation of educational tourism programs on the interest in learning arts for high school students.

\section{METHOD}

This study uses a quantitative approach. This study's sample was 84 students who were the population sample, namely students who participated in art education tourism activities at UPI. The research instrument in the form of a questionnaire containing a list of questions to determine the educational program with a Likert scale categorization, namely very good (score 4 ), good (score 3), sufficient (score 2), and poor (score 1). Meanwhile, to determine the interest in learning art, using a Likert scale with category of always (score 4), often (score 3), sometimes (score 2), and never (score 1). The list of questions deve- loped concerns the indicator variables that focus on the problem of this study. The number of questions given to respondents was 20 items with each grouping of answer indicators, namely 10 question items for the variable implementation of the arts education tourism program in general and 10 question items to determine the respondents' answers about the tendency for changes. These questions are for asking students to learn art after participating in activities of the art education tourism program. Variables, indicators, and subindicators and grouping of questions are explained in Table 1.

Data analysis was performed using a simple regression test analysis with the help of SPSS 20. Significance testing was carried out with the provisions if the significant value $<0.05$, which means that the variable $X$ affects the variable $Y$. If the significant value $>0.05$, it means the variable $X$ does not affect the variable $Y$.

\section{RESULTS AND DISCUSSION}

\section{Art Education Tourism Program}

The development of art learning materials in schools must be endeavored to raise local wisdom art materials that pay attention to the principles of student development (Graham, 2007; Inwood \& Taylor, 2012; Mack, 2015; Song, 2012). Appreciation is one of the learning methods that can be done in art learning activities in schools to achieve the expected learning goals (Covington, 1999, 2000; Covington \& Dray, 2002; Dörnyei, 2007; Malarsih, 2016).

Table 1. Research Variables

\begin{tabular}{cccc}
\hline Variable & Indicators & Sub-Indicators & No Item \\
\hline $\begin{array}{c}\text { Art Education Tour- } \\
\text { ism }(\mathrm{X})\end{array}$ & Attraction & $\begin{array}{c}\text { Place of learning experience or loca- } \\
\text { tions and activities carried out }\end{array}$ & $1,2,3$ \\
& & Staffing, informant & 4,5 \\
& Human Resources & Program planning & 6,7 \\
& Travel Planning & Guide, marketing & $8,9,10$ \\
Tour Operator & Psychological conditions (Motiva- & $1,2,3,4,5,6$ \\
Students' Art Learn- & Internal Factors & tion, Talent, and Learning Interest & \\
& & Social environment (family, school, & $7,8,9,10$ \\
& External Factors & community) & \\
\hline & & &
\end{tabular}


This art education tourism program can be used as an alternative way for students to understand a material taught by the teacher.

Education and tourism are two different things, but they can synergize and complement each other. The educational process carried out in tourism activities is an active and creative learning method and is an effective alternative learning method. Educational tourism activities can be a means of socializing and fostering a sense of pride and love for culture and the nation. Educational tourism is a tourism activity carried out by tourists to obtain education and learning.

Dhiman (2012); Dredge et al. (2015); Sheldon, et al. (2008), and Xiao (1999) explained that educational tourism is a tourism activity carried out by those who take an overnight vacation or more and those who make a journey to find education and learning as either a primary or secondary part of their journey. Educational tourism, or in English known as edu-tourism is an activity to visit a location that has entertainment and educational value.

Educational tours vary, including conferences, research, student exchanges, seminars. Students do this by taking advantage of time according to the schedule by taking walks but gaining knowledge (Merriam, 2007; Jafari \& Ritchie, 1981). UPI, as an educational campus in Bandung, also provides the Art education tour package design, which was initiated around 2017. The Faculty of Art and Design Education, together with activists from FPSD organizations (SM FPSD, Himasra, Himastar, and Himamusik), are trying to make UPI as one of the new educational tourism options in Bandung.

The materials in the guidance have been adjusted to the quality of the students and the educational curriculum. Every time you visit a tourist attraction, it will be adjusted to the object's interest and the field of science that will be studied. Educational tourism aims to increase the intelligence and creativity of tourism activity participants. This educational tourism program will feature a variety of music and dance performances as well as workshops and art exhibitions. Some of the performances that have been performed are Ansambel Gitar, Regional Dances, and Batik Workshops.

Places that are usually used are in the Dome Theater of the UPI Indonesian National Education Museum or in the FPSD Building itself according to the number of participants who take it. The activity's target is students, but it cannot be denied that the public and other university students are also interested.

This educational tour is a form of UPI's concern in facilitating arts and cultural education so that it is expected to attract targets to learn it. This is also an effort to provide material to solve the limitations of deepening cultural arts material in schools. Some of the benefits of implementing edu-tourism are as follows:

Students can get direct experience from the object being seen; Students can participate in various activities so that they can develop their special talents or skills; Students can deepen and broaden their experiences; Students can find the truth of the proof of their theory or try their theory into practice, and Students can gain inseparable and integrated knowledge and experience.

The concept of educational tourism is deliberately designed specifically to meet students' scientific capacity as part of the additional material supplements provided at school; they can gain additional knowledge through educational tourism activities. The concept of educational tourism that is specifically carried out by students is for recreation for entertainment, but it has an educational idea in increasing the knowledge possessed by students through observing, interacting, questioning, experiencing, recognizing, and learning from the objects they visit.

Thus, they will be able to fill national insight with tourism travel activities to identify areas and potential local resources between regions, districts, provinces, and between islands throughout the country. 
Students' travel activities will be able to boost the economic growth of tourism management actors, as well as to re-develop the artistic and cultural potential of each region to be developed again through the concept of material products for the needs of educational tourism activities.

The quality of a tourist attraction has proven to be a major factor that will determine tourist satisfaction and ultimately will determine loyalty, which can be in the form of tourist interest in returning to visit or recommending destinations to others to visit (Hermawan, 2017; Weiermair, et al., 2007). So, UPI, as the organizer, needs to maintain the quality of the educational tourism program.

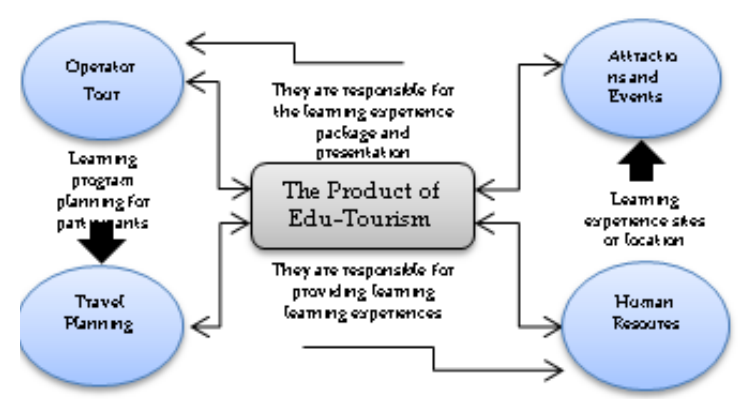

Figure 1. Concept of Educational Tourism Product Development (Ritchie \& Crouch, 2003)

According there are four indicators in seeing the potential and developing educational tourism products, they are: Attractions and events are places of learning experience or locations, and the activities carried out. Human resources or specialists are responsible for providing learning experiences. This could be like a guidebook, curator, lecturer or instructor, and guide. Travel planners, namely individuals, agents, or organizations, assist in planning and designing learning programs for participants. Tour Operators are those who are responsible for packaging and presenting educational experiences by providing expertise, local knowledge, and marketing services.

These four things need to be considered to develop educational tourism for the target object. If the four indicators are good, the objectives of the educational tourism program will arrive at the target. Educational tourism providers have an important role in developing tourist attractions as a result of initiative and creativity, as important elements in the strategy for developing educational tourism programs (Richardson \& Fluker, 2004)

\section{The Influence of Edu-tourism Program on Students' Art Learning Interest}

Interest in learning is the desire to make changes and improvements in a person, from not knowing to know, from being unable to be able, according to what they want (Rauf, 2013; Christensen-Scheel, 2018; Villacañas de Castro, et al., 2020). In simple terms, interest means a tendency and high excitement or a great desire for something. Internal or psychological factors of a person that affect interest in learning are students' intelligence, motivation, interests, attitudes, talents, and self-confidence. External factors of a person that influence interest in education are social environment, including family, school, and community.

Educational tourism program involves an experimental demonstration method where students see and observe various performances directly that will increase student understanding. (Kirchner \& Mostert, 2017) state that one's interest in something, combined with the use of strategy, will result in a higher level of achievement of results.

Thus, this study hypothesizes that the implementation of educational tours has a positive influence on students' interest in learning arts. Based on indicators used in preparing valid and reliable questionnaires, they were then distributed to samples in the field. The data obtained were tested using the SPSS 20 program. The results are as Table 2.

The Table 2 explains the significant effect of the educational program on students' interest in learning arts. From this output, it can be seen that the score of $\mathrm{F}$ count $=75.493$ with a significance level of $0.000<0.05$, then the null hypothesis is re- 
jected. Thus, it can be concluded that the regression model can be used to predict the variable of interest in learning arts, or in other words, there is the influence of the variable of educational program $(X)$ on the variable of interest in learning arts $(\mathrm{Y})$.

Table 2. Variance Analysis Test in Regression

Model Sum of df Mean F Sig

\begin{tabular}{lllllll} 
& Squares & & Square & & \\
\hline Regression & 211.065 & 1 & 211.065 & 75.493 & .000
\end{tabular}

Residual $229.257 \quad 82 \quad 2.796$

Total $\quad 440.321 \quad 83$

Dependent Variable: Interest in learning the art; Predictors: (Contant), Art Edu-tourism Program

Then, the coefficient of determination analysis is performed. The coefficient of determination is a number that shows the degree of ability to explain the independent variable to the dependent variable. The value of $\mathrm{R}$ is at zero and one $(0<$ $\mathrm{R}<1$ ). If the results get closer to one, the model results are good, and the level of closeness of the independent and dependent variables is getting closer too. Based on calculations using the SPSS 20 program, the results can be seen in the Table 3 .

Table 3. The Coefficient of Determination Analysis Model Summary

\begin{tabular}{ccrrr}
\multicolumn{5}{c}{ Model Summary } \\
\hline Model & $\mathrm{R}$ & $\begin{array}{c}\mathrm{R} \\
\text { Square }\end{array}$ & $\begin{array}{c}\text { Adjusted } \\
\text { R Square }\end{array}$ & $\begin{array}{c}\text { Std. Error of } \\
\text { the Estimate }\end{array}$ \\
\hline 1 & .692 & .479 & .473 & 1.67207 \\
\hline Predictors (Constant), Art Edu-tourism Program
\end{tabular}

The Table 3 explains the value of the correlation/relationship (R) equal to 0.692 . From this output, the coefficient of determination (R Square) of 0.479 implies that the education program's effect on the dependent variable (interest in learning arts) is $47.9 \%$.

Based on the Table 4, it is known that the value of Constant (a) is 10.303, while the value of the Education Program (b/ regression coefficient) is 0.603 , so the regression equation can be written:

$\mathrm{Y}=\mathrm{a}+\mathrm{bX}$ $Y=10,303+0,603 X$

The equation can be interpreted: A constant equal to 10.303 implies that the consistent value of the variable of interest in learning art is equal to 10.303 . The $\mathrm{X}$ regression coefficient of 0.603 states that for every $1 \%$ increase in the value of the edutourism program, it increases by 0.603 . The regression coefficient is positive, so it can be said that the direction of the influence of the variable $\mathrm{X}$ on $\mathrm{Y}$ is positive.

The analysis of the above calculations shows that the educational tour or educational tourism program is proven to have a positive influence on students' interest in learning arts. Interest in learning for each student is different. Students' interest in learning will determine the learning success process. Thus, instilling education for students requires a unique and effective learning process that can cause or attract students to participate in learning, so that good learning outcome is achieved. An educational tourism program can be an alternative.

The educational tourism program is an effort to add additional material provided at school. Students can gain additional knowledge and experience through educational tourism activities. The concept of educational tourism specifically carried out by students is not only for recreation for entertainment. So, students will be interested in the program being held.

Interest in learning becomes the students' desire; a high desire to learn ma-

Table 4. The Result of The Simple Regression Test

\begin{tabular}{|c|c|c|c|c|c|c|}
\hline \multirow[t]{2}{*}{ Model } & & \multicolumn{2}{|c|}{$\begin{array}{c}\text { Unstandardized } \\
\text { Coefficients }\end{array}$} & \multirow[t]{2}{*}{$\begin{array}{c}\text { Standar-dized } \\
\text { Coeffici-ents }\end{array}$} & \multirow[t]{2}{*}{$\mathrm{t}$} & \multirow[t]{2}{*}{ Sig } \\
\hline & & Std. Error & Beta & & & \\
\hline (Constant) & 10.303 & 2.410 & & 4.276 & .000 & \\
\hline Program Eduwisata & .603 & .069 & .692 & & .000 & \\
\hline
\end{tabular}


kes students active in studying in their environment. Schools have high hopes for students to follow the learning process at school according to the rules that the school runs, in the sense that students follow the learning process to completion and participate in extra activities held by the school, especially in the arts.

Although there are many opinions about art, it can be concluded that art is an idea, a thought, a feeling that is manifested or expressed through certain elements, which are beautiful to meet human needs (Dharmawati, 2016; Tatarkiewicz, 1974; Kaye, 1994; Whybrow, 2010; Roms \& Edwards, 2012; Lambert, 2018).

Art is a human activity that gives pleasure to the artist himself. From a light activity, a person's hobby, to come to watch an exhibition of artworks alone, he or she has experienced joyful hearts. Involvement as an art actor is, of course, different, it can give a further experience of pleasure more fully because all the attention of his senses is concentrated on the activities of his imaginary power which are revealed and reflected on the available equipment or art medium to appear as his work.

Indriyanti \& Sari, 2017 explain that students' interest in learning in arts subjects can be increased by the roles of various parties, especially how teachers as learning media/mediators and schools as supporting facilitators in learning. Material selection, teacher techniques in providing lessons to physical facilities such as electronic media and conducive conditioning for students' learning places so that the understanding of lessons will be maximized and students' interest in learning will increase.

The related opinion, the limitations of teachers in delivering material, and the limitations of physical facilities can be supported by collaboration with other parties, such as UPI FPSD, to provide other experiences outside of school for their students. That way, students can directly observe the various focus of art lessons.

Besides, UPI itself, especially FPSD, has a compatible vision and mission that this educational tour should be promotional material for those interested in art to enter UPI through several accessible channels, including SNMPTN, SBMPTN, and SM UPI. After becoming a student, every student must have physical, mental, and time readiness because, in the lecture process, a lot of time is spent on practicing the arts. However, it is not enough just to be proficient in playing musical instruments, proficient in theater, good at dancing and painting, because educational theories and theories on art must also be considered with a percentage of $30 \%$ educational theory, $30 \%$ art theory, and $40 \%$ practice.

\section{CONCLUSION}

Organizing educational tours as an alternative to learning has been proven to positively influence the interest in learning arts for high school students. Active and creative learning methods, as well as an alternative to effective learning methods. Students are also given in-depth and additional material not found in school by seeing the various performances and art workshops displayed in the implementation of the art education tourism program at UPI.

The results of data analysis show that the arts education tourism program has a significant influence on changes in high school students' art learning interest. This data is seen from the data analysis results using SPSS with the output data from the analysis test results obtained by the coefficient of determination (R Square) of 0.479 . This analysis proves that the influence of art education tourism programs (variable $\mathrm{X}$ ) on the dependent variable (interest in learning art) is $47.9 \%$. This means that art education tours can generate interest in learning art for students, which is influenced by students' internal and external factors.

\section{REFERENCES}

Andriana, A. (2017). Pengaruh Lingkungan Sekolah Terhadap Minat Belajar Siswa 
Kelas XI MA Wasilatul Falah Rangkasbitung.

Arici, H. E., Ertürk, M., \& Orcan, O. (2014). A Study on Educational Tourism: Impacts of Foreign Students on The Perception of Local Turkish Students: Evidence From Northern Cyprus. Journal of Gastronomy and Studies, 2(1), 3-12.

Christensen-Scheel, B. (2018). An art museum in the interest of publicness: a discussion of educational strategies at Tate Exchange. International Journal of Lifelong Education, 37(1), 103-119.

Covington, M. V. (1999). Caring about learning: The nature and nurturing of subject-matter appreciation. Educational Psychologist, 34(2), 127-136.

Covington, M. V. (2000). Goal theory, motivation, and school achievement: An integrative review. Annual Review of Psychology, 51(1), 171-200.

Covington, M. V, \& Dray, E. (2002). The developmental course of achievement motivation: A need-based approach. In Development of achievement motivation (pp. 33-56). Elsevier.

Dharmawati, M. (2016). Analisis prediksi kebangkrutan bank dengan model altman, zmijewski dan spiiringate pada perusahaan perbankan yang listing di BEI tahun 2012-2014/ Melly Dharmawati. Jakarta: Universitas Tarumanegara.

Dhiman, M. C. (2012). Employers' perceptions about tourism management employability skills. Anatolia, 23(3), 359-372.

Dörnyei, Z. (2007). Creating a motivating classroom environment. In International handbook of English language teaching (pp. 719-731). Springer.

Dredge, D., Schott, C., Daniele, R., Caton, K., Edelheim, J., \& Munar, A. M. (2015). The tourism education futures initiative. Anatolia, 26(2), 340346.

Graham, M. A. (2007). Art, Ecology and Art Education: Locating Art Education in a Critical Place-based Pedagogy. Studies in Art Education, 48(4),
375-391.

Hasanah, F. I. (2018). Eduwisata Desa Wisata Tamanan, Bondowoso sebagai Objek Perancangan Media Promosi melalui Desain Komunikasi Visual. Fakultas Seni Rupa dan Desain.

Hermawan, H. (2017). Pengaruh Daya Tarik Wisata, Keselamatan, Dan Sarana Wisata Terhadap Kepuasan Serta Dampaknya Terhadap Loyalitas Wisatawan: Studi Community Based Tourism di Gunung Api Purba Nglanggeran. Media Wisata, 15(1). Indriyanti, P., \& Sari, D. I. P. (2017). Eksplorasi Minat Belajar Siswa Dalam Mata Pelajaran Seni Tari di SD Taman Muda Ibu Pawiyatan Yogyakarta. Sosiohumaniora: Jurnal Ilmiah Ilmu Sosial Dan Humaniora, 3(1).

Inwood, H. J., \& Taylor, R. W. (2012). Creative Approaches to Environmental Learning: Two Perspectives on Teaching Environmental Art Education. International Electronic Journal of Environmental Education, 2(1), 65-75.

Jafari, J., \& Ritchie, J. R. B. (1981). Toward a framework for tourism education: Problems and prospects. Annals of Tourism Research, 8(1), 13-34.

Kaye, N. (1994). Live art: Definition and documentation. Contemporary Theatre Review, 2(2), 1-7.

Kirchner, E., \& Mostert, M. L. (2017). Aspects of the reading motivation and reading activity of Namibian primary school readers. Cogent Education, $4(1), 1-20$.

Lambert, C. (2018). The live art of sociology. Routledge.

Lisetskaya, E., Pavlenko, T., \& Dudina, E. (2019). Art and design academy for children: a modern learning environment for nurturing talents. Proceedings of the 14th International Academic Conference 2019, 216-221.

Mack, D. (2015). The Development of Art Learning Model at School (A Review of Music Education Learning in Indonesia). Harmonia: Journal of Arts Research and Education, 15(1), 1-8.

Malarsih, M. (2016). The Tryout of Dance 
Teaching Media in Public School in The Context of Appreciation and Creation Learning. Harmonia: Journal of Arts Research and Education, 16(1), 95-102.

Merriam, S. B., \& Brockett, R. G. (2007). The profession and practice of adult education: An introduction. John Wiley \& Sons.

Morellato, M. (2014). Digital Competence in Tourism Education: Cooperativeexperiential Learning. Journal of Teaching in Travel \& Tourism, 14(2), 184-209.

Rauf, D. A. (2013). Meningkatkan Minat Belajar Siswa Tentang Globalisasi Melalui Model Pembelajara Kooperatif Tipe Snowball Throwing Di Kelas IV SDN 24 Pulubala Kabupaten Gorontalo. Skripsi, 1(151409260).

Richardson, J. I., \& Fluker, M. (2004). Understanding and managing tourism. Pearson Education Australia.

Ritchie, J. R. B., \& Crouch, G. I. (2003). The competitive destination: A sustainable tourism perspective. Cabi.

Roms, H., \& Edwards, R. (2012). Towards a Prehistory of Live Art in the UK. Contemporary Theatre Review, 22(1), 17-31.

Sabri, I., Jazuli, M., Sumaryanto, T., \& Abdillah, A. (2019). Jemek Supardi, Mime Artist Indonesia (A Study of Life History). Humanus, 18(1), 40-48.

Sheldon, P., Fesenmaier, D., Woeber, K., Cooper, C., \& Antonioli, M. (2008). Tourism Education Futures, 20102030: Building the Capacity to Lead. Journal of Teaching in Travel \& Tour- ism, 7(3), 61-68.

Song, Y. I. K. (2012). Crossroads of public art, nature and environmental education. Environmental Education Research, 18(6), 797-813.

Sunaryo, A., Masunah, J., Narawati, T., \& Nugraheni, T. (2020). Gerak Relationship Pada Permainan Anak Sunda Sebagai Sumber Penciptaan Komposisi Tari Anak. Jurnal Obsesi: Jurnal Pendidikan Anak Usia Dini, 4(2), 1076-1086.

Suprihanto, J., Muhamad, M., \& Nugraheni, A. I. P. (2020). Potensi Proses Transformasi Sosial dalam Upaya Menumbuhkembangkan Wisatawan Bertanggungjawab dalam Meningkatkan wisata Berkelanjutan di Desa Wisata Nglinggo, Samigaluh, Kulon Progo.

Tatarkiewicz, W. (1974). The Definition Of Art. Soviet Studies in Philosophy, 12(4), 64-79.

Villacañas de Castro, L. S., Moreno-Serrano, L. M., \& Giner Real, C. (2020). Museum education, cultural sustainability, and English language teaching in Spain. Pedagogy, Culture $\mathcal{E}$ Society, 1-23.

Weiermair, K., Peters, M., \& Schuckert, M. (2007). Destination Development and the Tourist Life-cycle: Implications for Entrepreneurship in Alpine Tourism. Tourism Recreation Research, 32(1), 83-93.

Whybrow, N. (2010). Art and the City. Bloomsbury Publishing.

Xiao, H. (1999). Tourism education in China: Past and present. Asia Pacific Journal of Tourism Research, 4(2), 68-72. 